\title{
Adaptive Management Fitness of Watersheds
}

\author{
Ignacio Porzecanski $^{1}, \underline{\text { Lynn V. Saunders }}^{2}$, and Mark T. Brown ${ }^{3}$
}

\begin{abstract}
Adaptive management (AM) promises to improve our ability to cope with the inherent uncertainties of managing complex dynamic systems such as watersheds. However, despite the increasing adherence and attempts at implementation, the AM approach is rarely successful in practice. A one-size-fits-all AM strategy fails because some watersheds are better positioned at the outset to succeed at AM than others. We introduce a diagnostic tool called the Index of Management Condition (IMC) and apply it to twelve diverse watersheds in order to determine their AM "fitness"; that is, the degree to which favorable adaptive management conditions are in place in a watershed.
\end{abstract}

Key Words: Adaptive Management; decision-making; environmental condition; indicators; management prescriptions; watersheds

\section{INTRODUCTION}

There is little doubt that improved management of the world's fresh water is one of the most pressing issues facing us as a society today. At the heart of the myriad challenges of watershed management is the complex, dynamic, and often unpredictable interplay of the human and ecological domains. Increasing recognition of the inherent uncertainties present in watersheds as complex social-ecological systems is shifting our awareness of how to approach both new and old management challenges alike. By acknowledging that our understanding of any given system is and will always be imperfect, it is logical that our management approach should be experimental rather than reactive (Lee and Lawrence 1986, Lee 1993, Lee 1999, de Groot and Lenders 2006, Plummer 2009). This paradigm shift, coupled with escalating uncertainties associated with global climate change, has led many scientists and decision-makers to embrace adaptive management for managing water resources.

Adaptive management (AM) has been described as "an integrated, multidisciplinary and systematic approach to improving management and accommodating change by learning from the outcomes of management policies and practices" (Holling 1978). AM acknowledges and proposes to embrace the uncertainties inherent in predicting the ecological and social outcomes of our management decisions (Holling and Meffe 1996). Deliberate, ongoing experimentation lays the foundation upon which AM is built. As Benson and Garmestani (2011) have described it, AM is not simply "learning by doing" or responding to information with mitigation. The "active" form of AM involves simultaneous testing of multiple hypotheses about system management. Thus, in active adaptive management, policies are put "at risk" and learning is generated from successful and failed policies (Walters 2002, Allan and Curtis 2005, Garmestani et al. 2009). "Passive" AM often uses predictive models based upon ecological information to develop a policy for managing the system; monitoring and evaluation must take place, and adaptations and improvements to the model can then be made. Both "active" and "passive" forms of AM are different approaches to understanding and learning for management purposes. Most scholars and practitioners agree that AM calls for the restructuring of governance institutions at an appropriate bioregional scale, the active inclusion of stakeholders, and deliberate experimentation designed to encourage a continuous learning process that is incorporated into policy and management decisions (Huitema et al 2009). In AM, policies become hypotheses and management actions are the experiments to test these hypotheses. Scientists assume a new role in an AM context, shifting from experts to "one of several actors in the learning and knowledge generation process" (Folke et al. 2005). While AM has great potential for improved resource management in theory, in practice, it has rarely succeeded (Allan and Curtis 2005). There are many reasons for its lack of adoption and success, but the roots can often be traced back to an unfavorable AM context with respect to the governing institutions and policies in place, the organizations and programs at work, and the relationships between stakeholders (Walters 1997, Walters 2007, Allen and Gunderson 2011). In essence, as a result of the prevailing relationships among stakeholders and management agencies, some watersheds are better positioned at the outset to succeed at AM than others (Cohen and Davidson 2011).

Here we propose a diagnostic tool called the Index of Management Condition (IMC) to evaluate propensity towards successful AM within diverse watersheds. We introduce the framework for the IMC, and demonstrate its use by applying it to twelve watershed case studies. Drawing examples from these case studies, we identify underlying management attributes that most hinder or support successful implementation of AM practices and consider how institutions might be re-envisioned to better foster an effective AM paradigm.

\footnotetext{
${ }^{1}$ School of Natural Resources and Environment, University of Florida., ${ }^{2} \mathrm{H}$. T. Odum Center for Wetlands Phelps Lab, University of Florida, Gainesville., ${ }^{3} \mathrm{H}$. T. Odum Center for Wetlands Phelps Lab, University of Florida
} 
The proposed Index yields a comprehensive view of a watershed's management context to arrive at a measure of its overall "management condition"; that is, the degree to which sound water management is supported by the social and institutional structures in place. A watershed's IMC is a single number index derived from the sum of scores for 17 indicators, grouped within four categories (Table 1): (1) Ecological, (2) Social, (3) Institutional, and (4) Adaptive ManagementEnabling (AME). The Ecological, Social, and Institutional categories are similar in scope to those commonly found in the ecological and governance-based literature (ANZECC 2000, Mizrahi 2003, Brown and Vivas 2005, Arndt and Oman 2006, Walker et al. 2006, Ostrom 2009, Pahl-Wostl 2009, Gupta et al. 2010, Golet 2011, Knüppe and Pahl-Wostl 2011). The AME category distinguishes among those social and institutional characteristics that are generally regarded in the AM literature as specific to AM regimes (Pahl-Wostl et al 2007, Walters 2007, Raadgever et al. 2008, Huitema et al. 2009).

The relationships between the four IMC indicators may be conceptualized in a simplified manner by considering the parts of a "hinge" system (Figure 1). The two "wings" of the hinge represent the ecological and the social domains, and they are fixed to different parts of the larger system - the door and doorframe, for example - illustrating how these domains differ with respect to their epistemologies, beliefs, and traditions; yet, despite these differences they are mutually dependent. The social domain is influenced by and subsequently influences the ecological domain. The ecological and social domains are brought together by the institutional domain; i.e., the hinge "pin" in our analogy. The hinge pin represents the realm where the social and the ecological meet, each maintaining its individual set of characteristics, methods, and concerns, while being bound to each other. The institutional domain is an interpretation of the needs of the social-ecological domains and acts upon them through management and policy decisions. Hinges may be robust or weak, more or less resilient, and can fail or be repaired. AME characteristics provide the necessary "oil" for the social-ecological-institutional construct to work properly despite changing conditions and uncertainty.

The collection of 17 indicators that comprise the IMC is an attempt at being comprehensive in scope rather than in the depth with which each indicator may be defined and measured. It is also an attempt at reducing elements of great complexity to the ones most relevant for management purposes. Each indicator category may be further disaggregated into a greater number of indicators. However, it is worthy to note that in other indicator constructions in equally transcendental research fields such as medicine (Middlebrooks et al. 2008, McEwen and Gianaros 2010) and governance (Arndt and Oman 2006) indicator clarity and simplicity are usually prized for their ease of application. Thus, for our purposes of comparing many different watersheds, we opted to keep our indicators broad rather than highly detailed. Moreover, some users may wish to employ a more in-depth scoring system than the simplified approach we apply here. The salient point is that as long as a consistent approach is maintained to facilitate Index comparisons over time and between watersheds, the IMC may be modified as needed to best match the objectives and the quality of the available data.

Fig. 1. Schematic representation of our "hinge" analogy. The Ecological and the Social domains correspond to the fixed "wings" of a hinge, while the Institutional domain constitutes its "pin". AME factors function as the hinge's "lubricant".

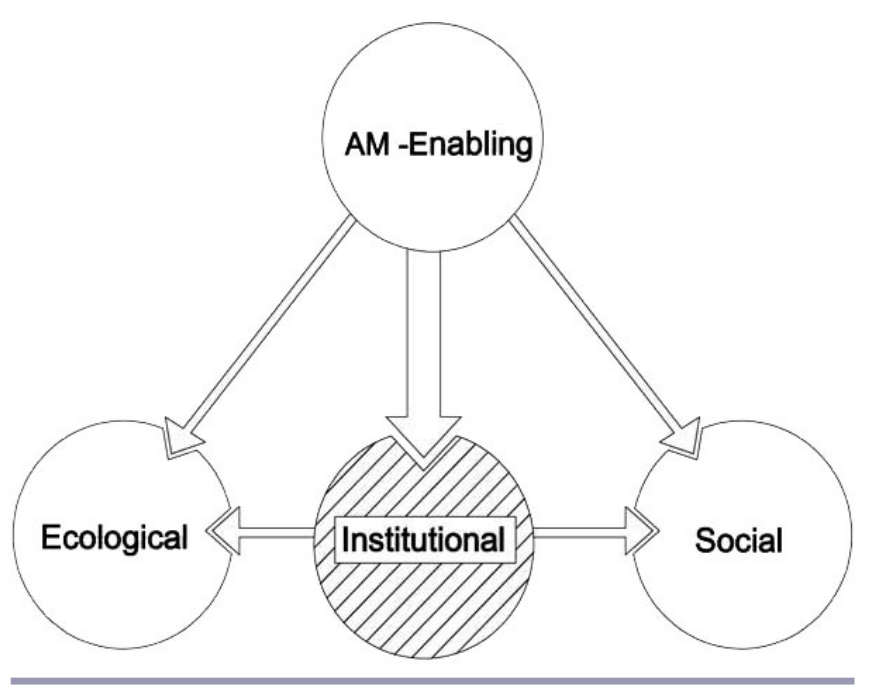

\section{METHODS}

The framework described above has been applied to twelve watersheds to examine how the IMC can be used to distinguish characteristics responsible for fostering or limiting the successful implementation of AM in practice. The twelve case studies examined here provide a diverse spectrum of water management contexts, from small to large, regional to international, highly managed to nearly non-managed, and very different socioeconomic realities (Table 2). Seven of the twelve watersheds are transboundary with three international and four interstate basins. These specific watersheds were selected by doctoral student teams participating in an adaptive management course as part of the curriculum for the Adaptive Management: Wise Use of Water, Wetlands and Watersheds Integrative Graduate Education and Research Traineeship (IGERT) at the University of Florida between the years 2006 and 2010. Student teams, with an average of four participants per team, each produced a watershed atlas which described in detail the biophysical environment of a selected watershed, analyzed the social-ecological relationships within them, and derived lessons regarding whether AM strategies could be 
Table 1. Definition of Index of Management Condition Indicators and the criteria used for scoring.

\begin{tabular}{|c|c|c|c|}
\hline Domain & Indicator & $\begin{array}{l}\text { Defined here as: } \\
\text { The degree to which... }\end{array}$ & $\begin{array}{l}\text { Evaluated in a watershed by looking for the } \\
\text { following: }\end{array}$ \\
\hline \multirow[t]{4}{*}{ Ecological } & Flow regime & $\begin{array}{l}\text { the natural water and sedimentation regime } \\
\text { has been disrupted }\end{array}$ & $\begin{array}{l}\text { presence and magnitude of dams, flow control } \\
\text { structures }\end{array}$ \\
\hline & Water, sediment/soil quality & $\begin{array}{l}\text { contaminating substances from point and non- } \\
\text { point sources are present in the river system }\end{array}$ & $\begin{array}{l}\text { measurements of water and sediment/soil } \\
\text { quality data exceeding acceptable levels; non- } \\
\text { compliance of TMDLs }\end{array}$ \\
\hline & Riparian ecosystem integrity & $\begin{array}{l}\text { disruption of the riparian environment has } \\
\text { occurred as the result of human activities }\end{array}$ & $\begin{array}{l}\text { loss of floodplain connectivity and wetlands; } \\
\text { bank erosion; proximity of urban/agricultural } \\
\text { development }\end{array}$ \\
\hline & $\begin{array}{l}\text { Biodiversity and food chain } \\
\text { integrity }\end{array}$ & $\begin{array}{l}\text { the richness, relative abundance, and } \\
\text { distribution of vegetation and wildlife has } \\
\text { been altered }\end{array}$ & $\begin{array}{l}\text { presence and magnitude of invasive/exotic } \\
\text { species; presence of threatened or endangered } \\
\text { species; absence of keystone species and/or } \\
\text { predators }\end{array}$ \\
\hline \multirow[t]{4}{*}{ Social } & $\begin{array}{l}\text { Participatory structures \& } \\
\text { networks }\end{array}$ & $\begin{array}{l}\text { stakeholders are empowered to participate in } \\
\text { the decision-making process }\end{array}$ & $\begin{array}{l}\text { number, durability, and strength of the } \\
\text { organizations that stakeholders build "bottom } \\
\text { up" in order to express their interests and } \\
\text { concerns }\end{array}$ \\
\hline & Well-being & basic human needs are met & $\begin{array}{l}\text { Income distribution; living/housing conditions, } \\
\text { employment of the watershed population } \\
\text { sectors; economic growth tendencies }\end{array}$ \\
\hline & Stakeholder equality & $\begin{array}{l}\text { stakeholders share power in the decision- } \\
\text { making process }\end{array}$ & $\begin{array}{l}\text { Presence, magnitude, and differences among } \\
\text { influential lobbying or economic groups, } \\
\text { NGOs. }\end{array}$ \\
\hline & Demand for ecosystem integrity & $\begin{array}{l}\text { the public is informed/aware of and involved } \\
\text { in watershed-related environmental and } \\
\text { managerial issues }\end{array}$ & $\begin{array}{l}\text { Active public participation in organizations, } \\
\text { campaigns and public hearings that articulate } \\
\text { environmental needs and demands }\end{array}$ \\
\hline \multirow[t]{4}{*}{ Institutional } & Stability & $\begin{array}{l}\text { management organizations meet their } \\
\text { responsibilities and implement decisions } \\
\text { independently }\end{array}$ & $\begin{array}{l}\text { time scale that the institutional structure has } \\
\text { been in operation; record of management } \\
\text { decisions and interventions in management } \\
\text { plans and monitoring activities }\end{array}$ \\
\hline & Transparency \& Accountability & $\begin{array}{l}\text { management processes are clear and accessible } \\
\text { to the stakeholders. }\end{array}$ & $\begin{array}{l}\text { interactions between management and local } \\
\text { organizations are fluid and permanent }\end{array}$ \\
\hline & Legal Instruments & $\begin{array}{l}\text { enforceable, effective and sound regulatory } \\
\text { frameworks exist }\end{array}$ & $\begin{array}{l}\text { norms are enforced; there exists a high level of } \\
\text { compliance }\end{array}$ \\
\hline & Planning Capacity & $\begin{array}{l}\text { management authorities possess the ability, the } \\
\text { human resources, and the autonomy to design } \\
\text { management initiatives }\end{array}$ & $\begin{array}{l}\text { presence of high quality, up-to-date } \\
\text { management plans }\end{array}$ \\
\hline \multirow[t]{5}{*}{ AM-Enabling } & Empowering Structures & $\begin{array}{l}\text { management authorities promote and share } \\
\text { management decisions with stakeholders }\end{array}$ & $\begin{array}{l}\text { number and role(s) of stakeholder } \\
\text { organizations directly involved in the decision- } \\
\text { making processes }\end{array}$ \\
\hline & Effectiveness & $\begin{array}{l}\text { management authorities possess the capacity } \\
\text { and leadership to move the management } \\
\text { process forward }\end{array}$ & $\begin{array}{l}\text { management plans are implemented and put } \\
\text { into practice; policies are established and } \\
\text { enforced }\end{array}$ \\
\hline & Experimentation & $\begin{array}{l}\text { the management context is conductive to } \\
\text { adaptive experimentation }\end{array}$ & $\begin{array}{l}\text { managers and scientists have an environment } \\
\text { where they collaborate and agree upon on the } \\
\text { design and execution of experiments; } \\
\text { appropriate experimental scale (both spatial } \\
\text { and temporal); appropriate levels of risk and } \\
\text { uncertainty }\end{array}$ \\
\hline & Information \& Learning & $\begin{array}{l}\text { knowledge about the watershed and its } \\
\text { uncertainties is recognized and openly } \\
\text { discussed }\end{array}$ & $\begin{array}{l}\text { strong linkages to academic institutions and } \\
\text { research structures }\end{array}$ \\
\hline & Financial Resources & $\begin{array}{l}\text { financial resources are sufficient and reliable } \\
\text { to support management activities }\end{array}$ & $\begin{array}{l}\text { history of sufficient financial support and } \\
\text { regularity of funding according to established } \\
\text { policy }\end{array}$ \\
\hline
\end{tabular}

discerned, recommended, or prescribed. No attempt was made to select similar watersheds in size, status, or geography. On the contrary, expressed interest was manifested in tackling a variety of contexts in order to be able to detect differences. Data availability, however, was a consideration in the selection process. Information detailed in the watershed atlases was 
Table 2. General characteristics of the twelve watersheds considered in this study.

\begin{tabular}{|c|c|c|c|c|c|}
\hline Basin Name & Scale & $\begin{array}{l}\text { Population } \\
\text { (millions) }\end{array}$ & $\begin{array}{l}\text { River Length }(\mathrm{km}) / \\
\text { Basin Size }\left(\mathrm{km}^{2}\right)\end{array}$ & Primary water uses & Major water resource issues \\
\hline $\begin{array}{l}\text { Apalachicola- } \\
\text { Chattahoochee- } \\
\text { Flint }\end{array}$ & $\begin{array}{l}\text { Interstate (Alabama, } \\
\text { Florida, Georgia) }\end{array}$ & $\begin{array}{l}6 \text { (most in } \\
\text { Atlanta, } \\
\text { GA) }\end{array}$ & $\begin{array}{l}843 / \\
48,500\end{array}$ & $\begin{array}{l}\text { Urban and agricultural water } \\
\text { supply, fisheries }\end{array}$ & $\begin{array}{l}\text { Adequate timing and quantity of } \\
\text { river flow }\end{array}$ \\
\hline Columbia & $\begin{array}{l}\text { International } \\
\text { (British Columbia, Idaho, } \\
\text { Oregon Washington, } \\
\text { Montana) }\end{array}$ & 3.7 & $\begin{array}{l}2000 / \\
675,000\end{array}$ & $\begin{array}{l}\text { Hydropower, irrigation, water } \\
\text { supply, navigation and recreation }\end{array}$ & $\begin{array}{l}\text { "Most dammed river system in the } \\
\text { world", flooding, impact of dams } \\
\text { upon fisheries (endangered } \\
\text { salmon) }\end{array}$ \\
\hline Crocodile & $\begin{array}{l}\text { International } \\
\text { (South Africa, Swaziland, } \\
\text { Mozambique) }\end{array}$ & 0.6 & $\begin{array}{l}320 / \\
10,450\end{array}$ & $\begin{array}{l}\text { Irrigation, tourism, wildlife } \\
\text { conservation }\end{array}$ & Water scarcity and human poverty \\
\hline Fraser & $\begin{array}{l}\text { Provincial (British } \\
\text { Columbia) }\end{array}$ & 3.3 & $\begin{array}{l}1375 / \\
234,000\end{array}$ & $\begin{array}{l}\text { Salmon fisheries, irrigation, } \\
\text { urban water supply, } \\
\text { transportation, recreation }\end{array}$ & $\begin{array}{l}\text { Estuarine water quality, Flooding, } \\
\text { Negative impacts to fisheries } \\
\text { (endangered salmon) }\end{array}$ \\
\hline Hudson & $\begin{array}{l}\text { Interstate } \\
(5 \text { states, } 93 \% \text { in NY) }\end{array}$ & 8 & $\begin{array}{l}508 / \\
34,500\end{array}$ & Urban water supply, irrigation & $\begin{array}{l}\text { Contaminated sediments, water } \\
\text { quality, invasive species (water } \\
\text { chestnut, zebra mussels) }\end{array}$ \\
\hline King's Bay \& & Regional/Local & 0.1 & $11 /$ & Urban water supply, & Water quantity and quality in \\
\hline Crystal River & ( 1 county, Florida) & & 637 & Conservation/tourism & $\begin{array}{l}\text { King's Bay; invasive aquatic } \\
\text { macrophytes; endangered manatee }\end{array}$ \\
\hline Ocklawaha & $\begin{array}{l}\text { Regional } \\
\text { ( } 5 \text { counties, Florida) }\end{array}$ & 0.3 & $\begin{array}{l}177 / \\
7200\end{array}$ & $\begin{array}{l}\text { Urban and agricultural supply, } \\
\text { recreation }\end{array}$ & $\begin{array}{l}\text { Channelization, water quality } \\
\text { (nitrogen and phosphorus), } \\
\text { invasive macrophyte species }\end{array}$ \\
\hline Peace & $\begin{array}{l}\text { Regional } \\
\text { ( } 4 \text { counties, Florida) }\end{array}$ & 0.8 & $\begin{array}{l}241 / \\
6086\end{array}$ & $\begin{array}{l}\text { Phosphate mining, urban and } \\
\text { agricultural supply }\end{array}$ & $\begin{array}{l}\text { Saltwater intrusion, water quantity/ } \\
\text { quality in Charlotte Harbor }\end{array}$ \\
\hline Sacramento & $\begin{array}{l}\text { Regional } \\
\text { (California) }\end{array}$ & 2.0 & $\begin{array}{l}719 / \\
69,500\end{array}$ & $\begin{array}{l}\text { Urban and agricultural water } \\
\text { supply }\end{array}$ & $\begin{array}{l}\text { Water quantity and quality (esp. } \\
\text { salinity, mercury), flooding }\end{array}$ \\
\hline St. Mary's & $\begin{array}{l}\text { Interstate } \\
\text { (Georgia, Florida) }\end{array}$ & 0.01 & $\begin{array}{l}209 / \\
4170\end{array}$ & $\begin{array}{l}\text { Industry, agriculture, } \\
\text { commercial and recreational } \\
\text { fishing }\end{array}$ & $\begin{array}{l}\text { Water quality (industrial effluents, } \\
\text { septic tanks) }\end{array}$ \\
\hline Suwannee & $\begin{array}{l}\text { Interstate } \\
\text { (Georgia, Florida) }\end{array}$ & 0.3 & $\begin{array}{l}394 / \\
27,684\end{array}$ & $\begin{array}{l}\text { Agriculture/silviculture, } \\
\text { recreation }\end{array}$ & Water quality (nitrates) \\
\hline Zambezi & $\begin{array}{l}\text { International } \\
\text { ( } 8 \text { countries, especially } \\
\text { Zambia, Zimbabwe) }\end{array}$ & 32 & $\begin{array}{l}4400 / \\
1.4 \text { million }\end{array}$ & $\begin{array}{l}\text { Hydroelectricity, mining, } \\
\text { subsistence agriculture, wildlife } \\
\text { conservation }\end{array}$ & $\begin{array}{l}\text { Severe poverty, disrupted flow/ } \\
\text { sedimentation regime due to } 86 \\
\text { dams }\end{array}$ \\
\hline
\end{tabular}

supplemented with additional studies and reports to arrive at IMCs that reflect, to the best of our knowledge, an up-to-date reality for each watershed.

We scored IMC indicators for each watershed on a three-point scale: (1) low, (2) average or (3) high. Indicator scoring for each watershed was performed independently by each of the authors and was generally consistent. Where there were scoring inconsistencies, further analyses were made to arrive at a consensus. Indicator scores were averaged for each indicator category (Ecological, Social, Institutional, and AME). Using the three-point scale, the IMC of a watershed may vary between values of 4.0 and 12.0 (the minimum average of 1.0 and the maximum of 3.0 for each of the four categories).

\section{RESULTS}

For the twelve watershed case studies, IMCs ranged from 4.7 to 11.4 with a mean score of 8.9 (see Appendix for individual scores and Figure 2 for a summary); three watersheds scored less than 8.0 and three higher than 10.0. Across all indicator categories the Zambezi watershed scored low and received the lowest IMC overall. This result is not surprising given the basin's extreme poverty and pervasive institutional weaknesses among its eight riparian nations (Angola, Botswana, Malawi, Mozambique, Namibia, Tanzania, Zambia, and Zimbabwe).

Equitable allocation of upstream-downstream water transferences is further complicated by the 86 dams found within the basin. Moreover, the urgent and ever-present struggle to address issues of poverty and human development consumes already limited resources and relegates many water management decisions to be driven by competing resource sectors such as the Ministries of Energy or Mines. Consequently, water management institutions across the basin are highly fragmented and policies poorly enforced. This low IMC reflects that the Zambezi watershed as a whole is a 
Fig. 2. IMCs with averaged indicator category scores for the twelve watersheds in this study. Possible scores for each indicator category range from 1.0 to 3.0. The number above each bar is the final IMC score for the watershed, calculated as the sum of its four category scores.

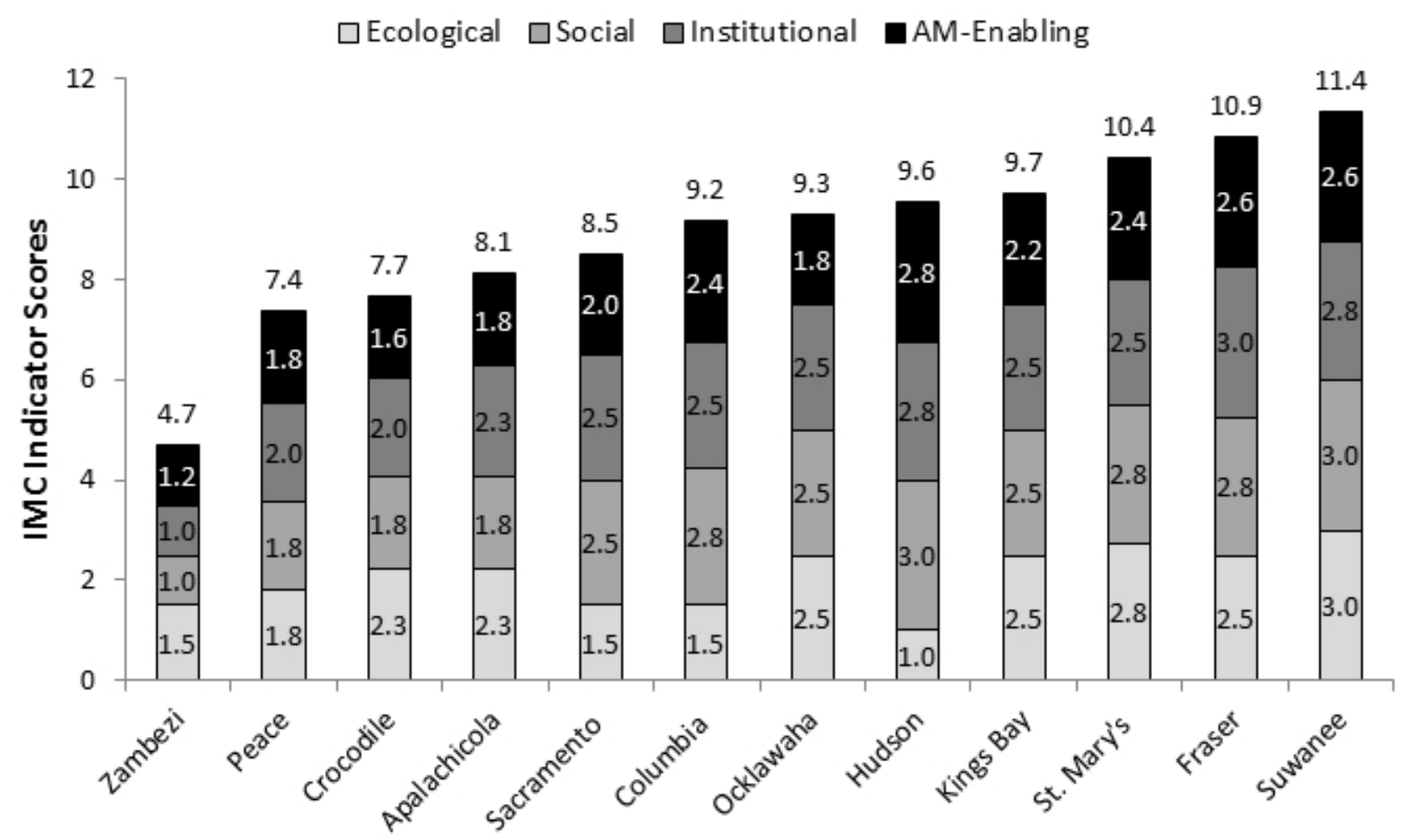

Watershed

volatile social-ecological system, particularly in the face of extreme uncertainty, such as climate change, which is predicted to exacerbate issues of poverty through the occurrence of more severe droughts (Beck and Bernauer 2010).

At the other end of the spectrum of our twelve cases studies is the relatively small and pristine Suwannee River watershed, located in southern Georgia and north central Florida of the US. The Suwannee scored high in all IMC indicator categories. Though the watershed lacks a basin-wide regulatory institution or an interstate compact, watershed-wide management decisions and research efforts are coordinated by the Suwannee River Interagency Alliance which is comprised of federal, state (Georgia and Florida) and regional organizations such as the Suwannee River Water Management District (SRWMD). The Suwannee River Partnership has been successful at building consensus among diverse stakeholder groups through voluntary, incentivized Best Management Practices (BMPs) in lieu of enforcing farmer compliance of Total Maximum Daily Loads (TMDLs). A long-term goal of developing a hydrologic observatory in the Suwannee River basin is being approached by numerous U.S. research institutions through the acquisition of federally-sponsored research grants. The creation of a hydrologic observatory will facilitate multiscale experimental studies across the watershed. In light of these many complementary factors, the Suwannee River watershed is likely an excellent candidate for implementing AM practices, perhaps most limited by longterm funding needed for large-scale experimentation.

The Suwannee and Zambezi watersheds represent cases where indicator scores were consistent across all indicator categories. In other cases, such as the Columbia and Hudson watersheds, IMCs were strongly biased by the ecological category score. Columbia's low ecological score reflects the presence of innumerable dams that have caused severe declines of salmon fisheries while in the Hudson both large dam systems and severely contaminated water and sediments are present. Low ecological scores reduced these watersheds' IMC despite their overall strong social and institutional scores. However, it is important to note that the ecological crises facing both these 
rivers have served as a catalyst for the emergence of the strong social and institutional structures in place today in these watersheds. In other words, while the ecological indicator does not represent current governance-related conditions per se, it nevertheless strongly influences them. This interdependency between the social and the ecological, and its resolution at the institutional level, provides a working illustration of our hinge analogy.

Overall, the watersheds presented in this study tended to score lowest in the AME category. While we might presume a priori that watersheds with high social and institutional scores might be better equipped for implementing AM strategies, we found that this might not always be the case. In fact, we also observed that for watersheds where AM strategies are, to varying degrees, already in place (Hudson, Columbia, Sacramento, Crocodile) or had been practiced in the past (Fraser) this precondition did not necessarily translate to high or low AME scores, respectively. The lack of congruity of these observations illustrates the difficulty of "translating" a relatively sound social-institutional base to an effective and functional AM process. These discrepancies are captured by the IMC framework, suggesting that the indicators that we present here, though admittedly broad and overly simplified, may nevertheless be effective at highlighting key differences among watershed management regimes. Herein lies the potential power of the IMC as a diagnostic tool for determining which watersheds are best equipped to employ AM strategies: where scores for the social-institutional indicators, even when favorable, are far from alignment with that of the AME indicators, AM processes in practice are likely to be jeopardized.

We examine which of the twelve watersheds are most disposed to incongruent $\mathrm{AM}$ and social-institutional characteristics by comparing the AM-enabling category score and the combined average of its social and institutional category scores (Figure $3)$. These $(x, y)$ values were plotted against a 1:1 line; the further the watershed deviates from the 1:1 line, the greater the lack of alignment between its AM-enabling and socialinstitutional scores. This lack of alignment was especially prominent in four watersheds - Columbia, Sacramento, Ocklawaha, and Apalachicola-Chattahoochee-Flint (ACF). In all four of these watersheds, AME scores were low relative to their social-institutional scores. Conversely, three watersheds fell into the so-called "zone of high AM fitness" where AM and social-institutional factors were both high and in alignment with each other. The three AM "fit" watersheds were the Hudson, Suwannee and Fraser. Using the IMC framework, these three watersheds are predicted to have the highest "AM fitness" and thus the greatest potential for successful implementation of AM strategies. In all twelve watersheds, we see that AME indicators scored lower than the combined social-institutional score; i.e., all values fell below the 1:1 line rather than above it. This observation makes sense intuitively since AME indicators represent a subset of the larger social and institutional context. Thus, AME characteristics as a whole can only function as well as the social-institutional frameworks in place.

Fig. 3. Identifying AM fitness using the IMC. AM fitness is the degree to which favorable AM conditions are in place in a watershed, as indicated by a watershedIII's proximity to the 1:1 line. The Hudson, Fraser, and Suwannee watersheds fell within the zone of III"high AM fitness III" (indicated by the dotted box), as their Social-Institutional scores were high and in 1:1 alignment with their respective AME scores. Outliers (italicized, bold) are those watersheds that exhibit low AME scores relative to their high Social-Institutional scores.

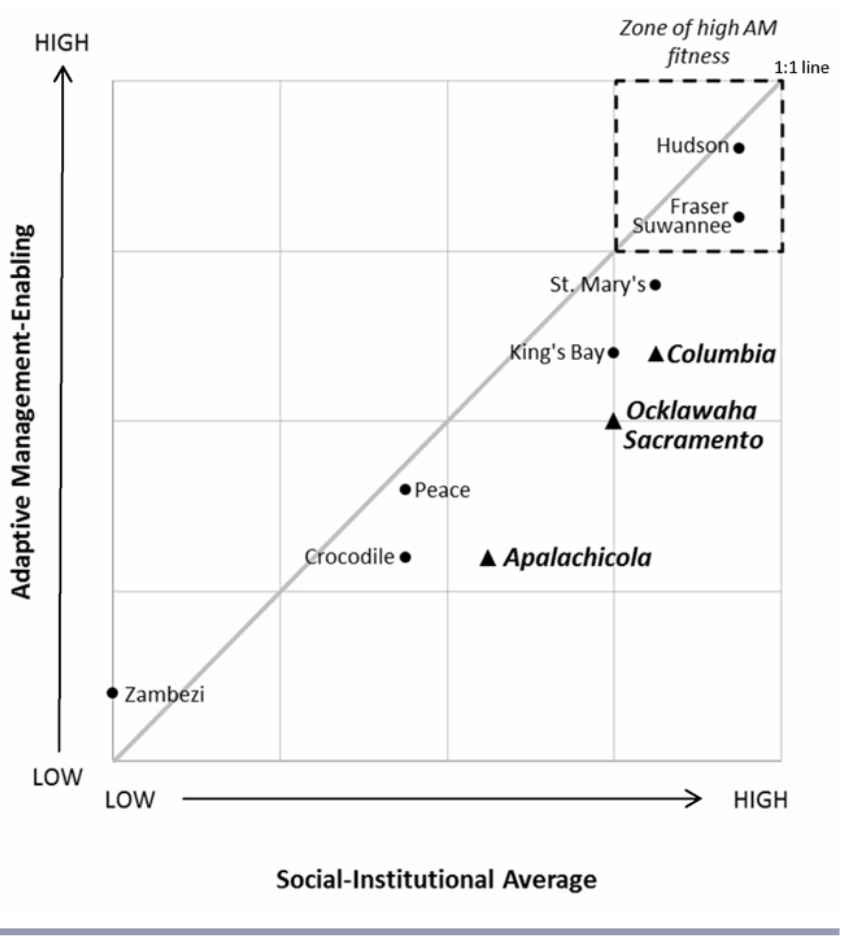

What are the underlying factors that differed between the "outliers" and the AM "fit" watersheds? What are the institutional distinctions that favor AM? To address these questions we first take a closer look at the Columbia watershed which scored as high for the social and institutional indicators as the three AM "fit" watersheds. However, in contrast to its high social and institutional scores, its incongruent midrange AM-enabling score reflects mixed conditions for successful adaptive management. On one hand, adaptive management for managing salmon-recovery efforts has been in practice since 1984 (Lee and Lawrence 1986) and one may assume that a long experience in AM has perfected its practice. This is partly true, especially regarding an improved stakeholder participation in decision-making processes (McLain and Lee 
Table 3. Common challenges and opportunities for watershed management and the adoption of AM practices. The degree to which each challenge or opportunity is present in a given watershed is indicated by "+" for a relevant challenge or opportunity and "++" for a major challenge or opportunity.

\begin{tabular}{|c|c|c|c|c|c|c|c|c|c|}
\hline & \multicolumn{4}{|c|}{ CHALLENGE } & \multicolumn{5}{|c|}{ OPPORTUNITY } \\
\hline & $\begin{array}{l}\text { Lack of } \\
\text { upstream- } \\
\text { downstream } \\
\text { cooperation }\end{array}$ & $\begin{array}{l}\text { Lack of } \\
\text { stake- } \\
\text { holder } \\
\text { equality }\end{array}$ & $\begin{array}{l}\text { Fragmented } \\
\text { policies and } \\
\text { legislation }\end{array}$ & $\begin{array}{l}\text { Non-conducive } \\
\text { experimentation } \\
\text { setting }\end{array}$ & $\begin{array}{l}\text { Watershed- } \\
\text { level water } \\
\text { management } \\
\text { authorities }\end{array}$ & $\begin{array}{l}\text { Multi-level } \\
\text { government } \\
\text { partnerships }\end{array}$ & $\begin{array}{l}\text { Watershed } \\
\text { councils for } \\
\text { planning/info } \\
\text { sharing }\end{array}$ & $\begin{array}{l}\text { Stake- } \\
\text { holder } \\
\text { incentive } \\
\text { programs }\end{array}$ & $\begin{array}{l}\text { Learning by } \\
\text { implementation } \\
\text { of AM: current, } \\
\text { in the past, or in } \\
\text { other sectors }\end{array}$ \\
\hline Apalachicola & ++ & ++ & ++ & + & ++ & & & & \\
\hline Columbia & + & & ++ & + & & & + & ++ & ++ \\
\hline Crocodile & + & ++ & ++ & + & ++ & ++ & & & ++ \\
\hline Fraser & & & ++ & & & ++ & ++ & & ++ \\
\hline Hudson & & & & & & & ++ & ++ & ++ \\
\hline King's Bay & & & + & & ++ & & ++ & & + \\
\hline Ocklawaha & ++ & + & + & + & ++ & & & & \\
\hline Peace & ++ & ++ & ++ & & ++ & & ++ & ++ & + \\
\hline Sacramento & + & + & ++ & + & ++ & & ++ & & ++ \\
\hline St. Mary’s & & & + & & ++ & ++ & & ++ & \\
\hline Suwannee & & & & & ++ & ++ & & ++ & \\
\hline Zambezi & ++ & ++ & ++ & ++ & & + & + & & \\
\hline
\end{tabular}

1996) however, there exist two primary sources of intractable problems that continue to plague adaptive management of fisheries in the basin. The first is the problem of dispersion of authority among relatively autonomous actors at the federal, state, municipal and tribal levels. To some degree this fragmentation is counterbalanced by the creation of the Northwest Power Conservation Committee (NPCC) as a centralized, neutral institution charged with making systemwide decisions and coordinating stakeholders; however the overall efficiency of the NPCC is diminished by its lack of authority to implement the management plans they create (Volkman and McConnaha 1993). Secondly, and perhaps a much more daunting a challenge to adaptive management in practice, is overcoming the inherent difficulties in carrying out experiments in the basin. The risks, costs and scale of comanaging endangered salmon populations and hydroelectricity is compounded by the salmon species complex life history and variable migration patterns which confound discernment of whether management strategies are meeting their objectives for increasing populations (McDonald et al 2007). These two broad AM limiting factors were accounted for in the IMC framework through decreased AME scores for "effectiveness," and "experimentation."

\section{ADAPTIVE MANAGEMENT CHALLENGES AND OPPORTUNITIES}

As we saw above for the Columbia River Basin, the examination of the social-institutional-AME context of a watershed from an IMC perspective helps to shed light on how the potential for AM in theory can be stopped short by pervasive challenges when put into practice. Through our IMC analyses of the twelve case studies, and particularly from our "outlier" watersheds, we found that many of the AM challenges can be classified into a small number of broad categories (Table 3 ). In some cases, these challenges to AM may be countered or overcome by opportunities manifested by the social-institutional domains as illustrated by our three "AM-fit" watersheds. The following discussion of these challenges and opportunities provides the narrative of how the IMC scoring is actually performed. Conversely, IMC scoring can be visualized as a tighter, more succinct means of depicting the presence of these fundamental challenges and opportunities.

\section{Upstream-downstream cooperation}

Adaptive management is not a conflict resolution strategy; where there are serious, irresolvable tensions between upstream and downstream water users, AM is likely to fail (Feldman 2008). At present, any meaningful basin-wide AM program in the $\mathrm{ACF}$ basin is precluded by the lack of consensus between Georgia, Florida and Alabama over the equitable apportionment of water. Similarly, the contentious debate over dam decommissioning in the Ocklawaha basin serves as another example, albeit at a much smaller scale, where successful basin-wide AM is limited due to enduring stakeholder conflict (Sloan 2005).

Transboundary compacts such as the Columbia River Treaty between the US and Canada illustrate an example of how to deal with conflicts between upstream-downstream users. Another approach is the creation of a neutral, third-party consensus-building organization such as the Northwest Power Planning Council (NPPC) and the Fraser Basin Council (FBC) in the US portion of the Columbia River and in the Fraser 
River basin in British Columbia (Blomquist et al. 2005), respectively. Other watersheds, such as the Suwannee and the St. Mary's have successfully avoided conflict by relying on intergovernmental agencies - the Suwannee River Interagency Alliance and the St. Mary's River Management Committee, respectively - with representatives from each state who are responsible for basin-wide decision-making and management planning activities. However, some institutional arrangements may not carry enough weight to prevent conflict when heated upstream-downstream water quantity and/or quality issues arise. In fact, as the ACF basin has clearly demonstrated, even in the presence of an interstate compact, agreements can and do fail. This reality may serve to caution other multiparty treaties such as those between South Africa, Swaziland and Mozambique in the Crocodile basin in southern Africa. At present, in the event that two of the states have a conflict, the third state can often act as an arbitrator. Swaziland is also in the unique position of being both downstream and upstream of South Africa, which provides them with leverage when negotiating with South Africa. However, in the case of an extreme and prolonged drought situation, there is the potential that water allocation agreements may not be honored by more than one nation leading to a fissure between all three countries.

Science-based policy directives based around measureable goals such as TMDLs and minimum flows have potential for mitigating or reducing transboundary conflict by providing common, defensible ground through objective, reportable and quantifiable compliance-driven agendas. As long as an atmosphere of trust and open communication exists, AM can provide the framework for the decision-making and experimental aspects of these approaches. Failures in collaboration can limit and impede the ability to conduct AM experiments (Smith 2011); therefore, the existence of watershed councils is a key feature in the ability to generate consensus.

\section{Stakeholder equality}

AM paradigms require a negotiating environment that is able to foster confidence, participation and shared power. Where these preconditions are lacking, adaptive management will not succeed (Stringer et al. 2006, Feldman 2008). In situations where stakeholder power is strongly imbalanced, adaptive management processes are likely to get hijacked by both blatant and hidden agendas (Allen and Gunderson 2011). Lack of equality among stakeholders occurs when a particular stakeholder or stakeholder interest group wields unequal power or representation in the decision-making process through unequal access to information, time, money, and/or skills (Huitema et al. 2009).

Approximately $75 \%$ of the ACF's population resides within metropolitan Atlanta, located at the upstream end of the watershed. Not surprisingly then, this growing population has held considerable sway over water use rights compared to their rural downstream counterparts. The city of Atlanta's disproportionate influence over water quantity and quality in the remaining ACF basin is a clear example of unequal power sharing. Another example can be found in the Ocklawaha basin in Florida where the fishing interests of a single stakeholder group, backed by a few powerful politicians, has halted restoration of the Ocklawaha River despite millions of dollars in scientific research that demonstrated the feasibility and benefits of river restoration and which is supported by every state or federal environmental protection agency including the governor and Cabinet (Hamann 2005a).

Another salient example of unequal stakeholder representation within our case studies is the phosphate mining industry in the Peace River watershed in Florida. The phosphate industry greatly influences the Florida economy with Florida's phosphate deposits providing a quarter of the world's phosphate supply. As a result of this, the phosphate mining industry's influence on State and federal environmental policy is unduly large, and can bend the rules regarding cumulative impacts analysis which aids mining applicants in the permitting process while minimizing the industry's accountability for causing negative, widespread and long-term environmental impacts to the watershed (Brown 2005). Where imbalances are present, public participation and suitable agency interventions may ultimately serve to reinforce them, rather than reduce them, unless "underprivileged" stakeholders are actively supported by organizers of participatory processes (Huitema et al. 2009). This role is often played by watershed councils or other organizations designed to build stakeholder consensus such as the NPPC and FBC described above for the Columbia and Fraser watersheds.

\section{Experimentation}

Deliberate, ongoing experimentation lays the foundation upon which AM is built. Some watersheds engaged in rhetoric regarding potential adoption of AM benefit greatly from past and present learning experiences from the region. Examples include AM previously used for forestry practices in the Fraser watershed, and currently those in place for wildlife management in Kruger National Park at the Crocodile River watershed. Decades of invasive plant management in the King's Bay/Crystal River watershed may perhaps constitute "passive AM", as it is not the rigorous and deliberate experimentation that intends to embrace uncertainty and reduce it in the process (Gregory et al. 2006).

Experimentation and learning in the AM context refers to at least two phenomena: (1) scientific experimentation to gain understanding about managing the watershed from an ecological perspective and (2) experimentation to improve management of the watershed from an institutional perspective. Both pose numerous challenges, but it is one of the premises of AM that we should be willing to accept the 
possibility, even the likelihood of failure, in the name of learning (Pahl-Wostl et al. 2007). However, significant failure at the science-policy interface yields an unfavorable position for politicians hoping to get reelected and who must approve implementation and authorization of funds. There is also the incompatibility between short political tenures and the long time horizons needed for scientific and governance experimentation.

These challenges are further compounded in high-stakes settings such as in the Columbia and the King's Bay-Crystal River watersheds where failures could mean further declines in endangered species populations such as salmon and manatee, respectively. Moreover, long-term experimentation can be expensive, both in terms of operational costs as well as opportunity costs, e.g. lost revenue by adjusting flow through hydroelectric turbines to allow fish passage. Finally, the creation of meaningful experimental designs presents formidable challenges to ensure that experiments take place at an appropriate temporal and spatial scale to capture representative data under controllable and replicable conditions (Gregory et al. 2006, Allen and Gunderson 2011). Given these myriad constraints, the passive form of AM is often the only feasible option for many watersheds.

\section{Organizational fragmentation and overlaps}

Adaptive management assumes that the social-ecological system must necessarily be viewed from a holistic perspective in order to confront sources of uncertainty and design meaningful experiments. Institutional fragmentation is a pervasive problem that erodes this foundation by creating barriers to implementing comprehensive management decisions and experimental policies. Fragmented institutions and policies surrounding water management can stem from a number of sources including overlapping and/or competing authority and responsibility for water resource management and decision-making. Not surprisingly, water policy fragmentation is likely to exist in large transboundary basins where water resources are shared between culturally diverse, economically insecure and politically unstable nations such as those found in the Zambezi and Crocodile watersheds.

However, fragmentation can also be pervasive in welldeveloped nations with robust institutional structures and traditions, often in attempts to decentralize power. Overlapping rights and authority levels have been at the cornerstone of salmon management challenges in the Fraser River basin (Pinkerton 1999) and the failure of CALFED in the Sacramento River basin (Hanemann and Dyckman 2009, Kallis et al. 2009). For example, comprehensive management of salmon fisheries in Fraser basin is confounded by the governance structure in British Columbia which grants municipal and First Nation autonomy over water and land use decisions. Municipal and tribal governments can each establish their own laws and regulations regarding salmon habitat protection thus creating a patchwork of disparate and often conflicting water and stream habitat decisions.

Fragmented policies resulting from the lack of comprehensive management may, in some cases, be intentional in order to accommodate the interests of influential stakeholders, as was observed at the Peace River watershed. In other cases, the fragmented policies reflect outdated practices that have yet to be changed due to institutional obstacles. A case in point is the lack of co-management policies for groundwater and surface water resources in the Sacramento River basin. Despite recognition of the importance of conjunctive management of surface and groundwater for meeting future urban and agricultural supply needs and for minimizing saltwater intrusion in the basin, this practice would require a fundamental change in the current agreements that govern surface water deliveries in the basin and thus have not yet been realized (Healey et al. 2008).

The King's Bay/Crystal River watershed provides an interesting example in which fragmented water policies can arise due to unclear physical boundaries. Water management districts in Florida use watershed boundaries as the template for delineating local and regional water management jurisdictions; however, the system boundary and area of influence of King's Bay/Crystal River is more accurately characterized by its patterns of groundwater flow, i.e., its springshed. Thus, incompatibilities between the real and managed boundaries of the system can lead to fragmented or misaligned management decisions by blurring the lines of responsibility. This issue is especially salient at King's Bay for determining how to prioritize management regarding the identification and mitigation of sources of pollutants that affect water quality and water clarity.

The problems of fragmentation have been addressed in some cases through restructuring of governance institutions. In many cases, these institutions are created at a watershed-level scale in an attempt to better match the scope of the "problemshed", i.e., the geographic area and all activities that contribute to the problem (Doremus 2009). Watershed-level institutions are created with the intention of resolving many of the failures found in traditional water resource institutions including the lack of cooperation among institutions, lack of stakeholder participation and the lack of recognition of interdependencies at the watershed scale (Huitema et al. 2009). The NPCC in the Columbia basin, the Water Management Districts in Florida and the Delta Blue Ribbon Vision Task Force (previously CALFED) in the Sacramento-San Joaquin basin in California provide examples of institutional restructuring of water governance at the watershed scale. While the degrees to which these institutions have succeeded in practice vary, they nevertheless demonstrate that despite a host of institutional barriers institutional restructuring is indeed possible (Hamann 2005b, Heikkila and Gerlak 2005). 
Moreover, while CALFED ultimately failed in delivering the desired management and policy outcomes, many argue that it ostensibly succeeded in transforming cultures, processes, languages and understandings (Bobker 2009).

Institutional overlap is at the cornerstone of polycentric governance and is often believed to provide resilience through redundancy (Ostrom 2005, Andersson and Ostrom 2008, Ostrom 2009). For the Columbia River, Cosens (2010) has argued for an administrative framework that substitutes the state and federal agency command-and-control approach for "an infusion of resources and capacity building at the local level, while retaining overlapping state, federal and international programs to provide oversight" and coordination. We have found, however, that if poorly conceived or managed, overlapping centers of shared responsibility are, in practice, very difficult to construct (Hooghe and Marks 2003) and operate. The fact that fragmentation and overlaps are the most important and frequent challenges found in our study suggests that management institutions are still focusing upon narrow sectors of the watershed (geographic or thematic) and are largely unable to discriminate, delegate, or come to terms with each other's jurisdictions in an effective manner. Resolving this issue requires either a much-improved level of coordination between the various parts designed to preserve the many centers of decision making at various scales, or a clearly centralized organization that oversees the entire agency constellation. In either case, coordination or oversight must be performed by an agency that has the capability of carrying out these tasks. Jurisdictional overlap and agency redundancy, we found, can lead to paralyzing bureaucratic roadblocks, and hinder the clarity, and the responsible assumption of commitment for effective AM action.

\section{CONCLUSIONS}

If $\mathrm{AM}$ is to be genuinely embraced, existing institutional frameworks themselves must adapt in order to accommodate new ways of sharing information, learning through deliberate experimentation, and incorporating learning into planning (Allan and Curtis 2005). Traditional command-and-control style management regimes cannot be easily substituted by a more "egalitarian-participatory" framework; rather, the responsibilities, the power and the means to manage, even after desirable institutional transformations, must continue to reside at some form of single or shared top structure that will effectively assume those responsibilities in a holistic, comprehensive framework. The IMC indicator analysis and the prevalence of noted challenges, such as institutional overlaps and fragmentation, show this to be a major obstacle to the adoption of sustainable AM in practice. They also point strongly to crucial differences in the mechanics of management and their history, as well as in the need to institute a committed AM-related atmosphere in order to avoid undesirable oscillations in policy implementation. As Nie
(2008) has written, "recognizing the necessity and legitimacy of regulatory enforcement is imperative if we are to move alternative conservation strategies forward".

The challenge lies in arriving at an appropriate balance between command-and-control and pluralistic, participatory governance in order to be simultaneously efficient and legitimate yet dynamic and open to change in the face of uncertainty and new information as learning advances. In some cases, a strongly hierarchical structure may be more flexible and dynamic than a polycentric governance regime, yet would require a trade-off of participation and democratization (Skelcher 2005, Ostrom 2011). Discovering an appropriate balance for each watershed is not likely to follow an institutional prescription for a pre-conceived notion of AM; rather, attention should be directed at how to create cohesiveness among the essential managerial and decisionmaking pieces. For this reason, an approach such as the IMC can be helpful because it keeps track of how the different domains and indicators adjust to each other at any point. That is, we understand generally which factors are relevant; what is difficult is to make the specific decisions regarding the right mixes of strength and flexibility, of research aims, and of collaboration or centralization for each case.

It emerges from our analysis that AM is not the appropriate strategy for all watersheds. Where there is little uncertainty, where the costs and risks are too high, where institutions are weak or dysfunctional, and where the experimental context does not permit meaningful experimentation, other management approaches should be pursued (Gregory et al. 2006, Allen and Gunderson 2011, Engle et al. 2011). However, even in situations when non-AM strategies are used, it is nevertheless prudent to promote active stakeholder participation and attempt to sustain enough flexibility within management and decision-making to allow for adaptation when the need becomes obvious (Williams 2011). We found that the social-institutional framework for the management of a watershed is not, in and of itself, a sufficient precondition for successful AM. Without the AME "oil" that includes adequate financial resources, active experimentation with open and effective pathways for learning, effective implementation of comprehensive policies, and engaged stakeholders, the "hinge" system as a whole will not thrive.

It would be tempting to establish that for a small and pristine watershed there corresponds a simple and tidy set of institutions that manage it successfully. Or, conversely, that for a large, complex transboundary watershed, there exists a tangled, poorly managed collection of institutions. However, we do not find such simple correspondences between the nature or size of the problems and the institutions responsible for their management because their management history depends upon how the problems are perceived. Small watersheds may be easier to manage than larger ones, but, in 
our cases, scale does not appear to be a useful determinant of how management fares -large, complex watersheds may be the subject of sophisticated and robust management actions (Columbia River), while smaller ones (Peace River) flounder under the weight of intractable ecological impairment and political complexities. PCBs in the Hudson's sediments, mercury in the Sacramento, coliform bacteria in the St. Mary's, the supply of water to the city of Atlanta, and the ravages of phosphate mining at the Peace are perceived differently and it is difficult to establish a ranking of problem-gravity independently of how the local populations express their awareness, of how economic interests factor in management, and how the local authorities, sometimes overlapping and redundant, make sense out of these interactions in each case. The IMC, precisely because practiced in a case-by-case and comprehensive manner, is able to bring out the specificities of each social-ecological relationship in each particular watershed.

The IMC serves as a diagnostic tool that enables scientists, managers, decision-makers and stakeholders to view a holistic picture of the current watershed management regime. It may be used in a number of ways depending upon the goals of the users: (1) to draw comparisons between watersheds to seek learning opportunities by highlighting where key operational differences among management regimes occur; (2) to examine over time how approaches are or are not working within a single watershed i.e., as a monitoring tool that allows to evaluate how the process is moving, where the bottlenecks lie, and where implementation requirements need to be addressed; and (3) to stimulate discussion between stakeholders and policy-makers in creating goals and visions for future watershed management (Bouleau et al. 2009, Stahl et al. 2011).

Responses to this article can be read online at:

http://www.ecologyandsociety.org/voll7/iss3/art29/

responses/

\section{Acknowledgments:}

This study was supported by NSF Award \#0504422; we appreciate the efforts of the IGERT Adaptive Management of Water, Wetlands and Watersheds (AM:W3) students and faculty at the University of Florida, Gainesville, for their contributions to this work including: Nathan Barassa Wangusi, Lorenzo Benini, Susanna Blair, Becky Blanchard, Megan Brown, Brian Camposano, L. Carlton, Anna Cathey, Matt J. Cohen, Bo Davidson, David Elliot, McKenzie Ezell, Lisa Gardner, Andrea Gaughan, Robin Globus, Hollie Hall, Richard Hamann, Jillian Jensen, Nathan Johnson, William Kanapaux, Ilan Kaufer, Sean King, Marie Kurz, Dina Liebowitz, Chris Long, Melissa Martin, Kathleen McKee, Sarah McKune, Nancy Montes, Michael Morgan, Michael Murray-Hudson, John November, Julie Padowski, Darina
Palacio, Gregory Parent, Rachel Pawlitz, David Pfahler, Anthony Pinzino, Narcisa Pricope, Noorie Rajvanshi, Susan Risko, Estelle Robichaux, C. Schmidt, Robert Schulte, Claire Sunquist, O.T. Thakadu, Louise Venne, and Deb Wojcik.

\section{LITERATURE CITED}

Allan, C., and A. Curtis. 2005. Nipped in the bud: why regional adaptive management is not blooming. Environmental Management 36(3):414-425. http://dx.doi.org/10.1007/s0026 7-004-0244-1

Allen, C. R., and L. H. Gunderson. 2011. Pathology and failure in the design and implementation of adaptive management. Journal of Environmental Management 92(5):1379-1384. htt p://dx.doi.org/10.1016/j.jenvman.2010.10.063

Andersson, K. P., and E. Ostrom. 2008. Analyzing decentralized resource regimes from a polycentric perspective. Policy Sciences 41:71-93. http://dx.doi.org/10.10 07/s11077-007-9055-6

Arndt, C., and C. Oman. 2006. Uses and abuses of governance indicators. OECD Development Centre Studies. OECD Publications, Paris, France. [online] URL: http://www.source oecd.org/development/9264026851

Australian and New Zealand Environment and Conservation Council (ANZECC). 2000. Core environmental indicators for reporting on the state of the environment. State of the Environment Reporting Task Force. Environment Australia, Canberra, Australia.

Beck, L., and T. Bernauer. 2010. Water scenarios for the Zambezi River Basin 2000-2050. ETH Zurich, Report from the Center for Comparative and International Studies, Zurich, Switzerland.

Benson, M. H. and A. S. Garmestani. 2011. Embracing panarchy, building resilience and integrating adaptive management through a rebirth of the National Environmental Policy Act. Journal of Environmental Management 92:1420-1427. http://dx.doi.org/10.1016/j.jenvman.2010.10.011

Blomquist, W. A., K. Calbick, and A. Dinar. 2005. Institutional and policy analysis of river basin management. The Fraser River Basin, Canada. World Bank Research Working Paper No. 3525. [online] URL: http://ssrn.com/abstr $\underline{\text { act }=673483}$

Bobker, G. 2009. The means do not justify the ends. A comment on CALFED. Environmental Science and Policy 12:726-728. http://dx.doi.org/10.1016/j.envsci.2009.06.002

Bouleau, G., C. Argillier, Y. Souchon, C. Barthélémy, and M. Babut. 2009. How ecological indicators construction reveals social changes -the case of lakes and rivers in France. 
Ecological Indicators 9:1198-1205. http://dx.doi.org/10.1016/ j.ecolind.2009.03.010

Brown, M.T. 2005. Landscape restoration following phosphate mining: 30 years of co-evolution of science, industry and regulation. Ecological Engineering 24:309-329. http://dx.doi.org/10.1016/j.ecoleng.2005.01.014

Brown, M. T., and M. B. Vivas. 2005. The Landscape Development Intensity Index. Environmental Monitoring and Assessment 101:289-309. http://dx.doi.org/10.1007/s10661-0 $\underline{\text { 05-0296-6 }}$

Cohen, A., and S. Davidson. 2011. An examination of the watershed approach: Challenges, antecedents, and the transition from technical tool to governance unit. Water Alternatives 4(1):1-14.

Cosens, B. 2010. Transboundary river governance in the face of uncertainty: resilience theory and the Columbia River Treaty. University of Utah Journal of Land Resources and Environmental Law 30(2):229-265.

de Groot, W. T., and H. J. R. Lenders. 2006. Emergent principles for river management. Hydrobiologia 565:309-316. http://dx.doi.org/10.1007/s10750-005-1921-7

Doremus, H. 2009. CALFED and the Quest for Optimal Institutional Fragmentation. Environmental Science and Policy 12:729-732. http://dx.doi.org/10.1016/j.envsci.2009.06.004

Engle, N. L., O. R. Johns, M. C. Lemos, and D. R. Nelson. 2011. Integrated and adaptive management of water resources: tensions, legacies and the Next Best Thing. Ecology and Society 16(1):19. [online] URL: http://www.ecologyandsociety. org/vol16/iss1/art19/

Feldman, D. L. 2008. Barriers to adaptive management: lessons from the Apalachicola-Chattahoochee-Flint compact. Society and Natural Resources 21:512-525. http://dx.doi.org/ $\underline{10.1080 / 08941920801905344}$

Folke, C., T. Hahn, P. Olsson, and J. Norberg. 2005. Adaptive governance of socio-ecological systems. Annual Review of Environment and Resources 30:471-473. http://dx.doi.org/10 $.1146 /$ annurev.energy.30.050504.144511

Garmestani, A. S., C. R. Allen, and H. Cabezas. 2009. Panarchy, adaptive management and governance: policy options for building resilience. 87(4):5 Nebraska Law Review [online] URL: http://digitalcommons.unl.edu/nlr/vol87/iss4/5

Golet, G. H. 2011. Using ecological indicators to evaluate ecosystem integrity and assess restoration success in the middle Sacramento River. The Nature Conservancy, Chico, CA, USA.
Gregory, R., D. Ohlson, and J. Arvai. 2006. Deconstructing adaptive management: criteria for applications to environmental management. Ecological Applications 16 (6):2411-2425. http://dx.doi.org/10.1890/1051-0761(2006)016 [2411:DAMCFA]2.0.CO;2

Gupta, J., C. Termeer, J. Klostermann, S. Meijerink, M. van den Brink, P. Jong, S. Nooteboom, and E. Bergsma. 2010. The Adaptive Capacity Wheel: a method to assess the inherent characteristics of institutions to enable the adaptive capacity of society. Environmental Science and Policy 13:459-471. http://dx.doi.org/10.1016/j.envsci.2010.05.006

Hamann, R. 2005a. Florida's water management framework. Pages 1-14 in J. T. Sholz, and B. Stiftel, editors. Adaptive Governance and Water Conflict: New Institutions for Collaborative Planning. Resources for the Future, Washington, D.C., USA.

Hamann, R. 2005b. The Power of the Status Quo. Pages 125-129 in J. T. Sholz, and B. Stiftel, editors. Adaptive Governance and Water Conflict: New Institutions for Collaborative Planning. Resources for the Future, Washington D. C., USA.

Hanemann, M., and C. Dyckman. 2009. The San Francisco Bay Delta: a failure of decision making capacity. Environmental Science and Policy 12(6):710-725. http://dx.d oi.org/10.1016/j.envsci.2009.07.004

Healey, M. C., M. D. Dettinger, and R. B. Norgaard, R. B., editors. 2008. The State of Bay-Delta Science. CALFED Science Program. Sacramento, CA, USA.

Heikkila, T., and A. K. Gerlak. 2005. The Formation of Largescale Collaborative Resource Management Institutions: Clarifying the Roles of Stakeholders, Science, and Institutions. Policy Studies Journal 33(4):583-612. http://dx.doi.org/10.11 11/j.1541-0072.2005.00134.X

Holling, C. S. 1978. Adaptive Environmental Assessment and Management. John Wiley and Sons, New York.

Holling, C. S., and G. K. Meffe. 1996. Command and control and the pathology of natural resource management. Conservation Biology 10(2):328-337. http://dx.doi.org/10.1046/ j.1523-1739.1996.10020328.x

Hooghe, L., and G. Marks. 2003. Unraveling the Central State, but How? Types of Multi-level Governance. American Political Science Review: 97(2):233-243.

Huitema, D., E. Mostert, W. Egas, S. Moellenkamp, C. PahlWostl, and R. Yalcin. 2009. Adaptive water governance: assessing the institutional prescriptions of adaptive (co-) management from a governance perspective and defining a research agenda. Ecology and Society 14(1):26. [online] URL: http://www.ecologyandsociety.org/vol14/iss1/art26/ 
Kallis, G., M. Kiparsky, and R. Norgaard. 2009. Collaborative governance and adaptive management: lessons from California's CALFED Water Program. Environmental Science and Policy 12(6):631-643. http://dx.doi.org/10.1016/ j.envsci.2009.07.002

Knüppe, K., and C. Pahl-Wostl. 2011. A Framework for the Analysis of Governance Structures Applying to Groundwater Resources and the Requirements for the Sustainable Management of Associated Ecosystem Services. Water Resources Management 25(13):3387-3411. http://dx.doi.org/ $\underline{10.1007 / \mathrm{s} 11269-011-9861-7}$

Lee, K.N. and Lawrence, J. 1986. Adaptive management: Learning from the Columbia River basin fish and wildlife program. Environmental Law 16:431-460.

Lee, K.N. 1993. Compass and Gyroscope: Integrating Science and Politics for the Environment. Island Press, Washington D.C.

Lee, K. N. 1999. Appraising adaptive management. Conservation Ecology 3 (2):3. [online] URL: http://www.con secol.org/vol3/iss2/art3/

McLain, R. J. and R. G. Lee. 1996. Adaptive Management: promises and pitfalls. Environmental Management. 20 (4):437-448. http://dx.doi.org/10.1007/BF01474647

McDonald L. L., R. Bilby, P. A. Bisson, C. C. Coutant, J. M. Epifanio, D. Goodman, S. Hanna, N. Hundy, E. Merrill, B. Riddell, W. Liss, E. J. Loudenslager, D. P. Philipp, W. Smoker, R. R. Whitney, and R. N. Williams. 2007. Research, Monitoring, and Evaluation of Fish and Wildlife Restoration Projects in the Columbia River Basin: Lessons Learned and Suggestions for Large-Scale Monitoring Programs. Fisheries, 32(12):582-590.[online] URL: http://dx.doi.org/10.1577/1548 -8446(2007)32[582:RMAEOF]2.0.CO;2

McEwen, B. S. and P. J. Gianaros. 2010. Central role of the brain in stress and adaptation: links to socioeconomic status, health, and disease. Annals of the New York Academy of Sciences 1186:190-222. http://dx.doi.org/10.1111/j.1749-663 2.2009.05331.x

Middlebrooks, J. S. and N. C. Audage. 2008. The effects of childhood stress on health across the lifespan. Centers for Disease Control and Prevention, National Center for Injury Prevention and Control, Atlanta, GA.

Mizrahi, Y. 2003. Capacity enhancement indicators: review of the literature. World Bank, WBI Evaluation Studies No. EG03-72. Washington, D.C., USA.

$\mathrm{Nie}$, M. 2008. The underappreciated role of regulatory enforcement in natural resource conservation. Policy Sciences 41(2):139-164. http://dx.doi.org/10.1007/s11077-008-9060-4
Ostrom E. 2005. Understanding Institutional Diversity. Princeton Univ. Press, Princeton, N.J., USA.

Ostrom, E. 2009. A general framework for analyzing sustainability of social-ecological systems. Science 325:419-422. http://dx.doi.org/10.1126/science.1172133

Ostrom, E. 2011. Background on the institutional analysis and development framework. Policy Studies Journal 39(1):7-27. http://dx.doi.org/10.1111/j.1541-0072.2010.00394.x

Pahl-Wostl, C., J. Sendzimir, P. Jeffrey, G. Berkamp, and K. Cross. 2007. Managing change toward adaptive water management through social learning. Ecology and Society 12 (2):30. [online] URL: http://www.ecologyandsociety.org/vol12/ iss $2 / \operatorname{art} 30 /$

Pahl-Wostl, C. 2009. A conceptual framework for analysing adaptive capacity and multi-level learning processes in resource governance regimes. Global Environmental Change 19(3):354-365. http://dx.doi.org/10.1016/j.gloenvcha.2009.06.001

Pinkerton, E. 1999. Factors in overcoming barriers to implementing co-management in British Columbia salmon fisheries. Conservation Ecology 3(2):2. [online] URL: http:// www.consecol.org/vol3/iss2/art2/

Plummer, R. 2009. The adaptive co-management process: an initial synthesis of representative models and influential variables. Ecology and Society 14(2):24. [online] URL: http:/ /www.ecologyandsociety.org/vol14/iss2/art24/

Raadgever, G. T., E. Mostert, N. Kranz, E. Interwies, and J. G. Timmerman. 2008. Assessing management regimes in transboundary river basins: do they support adaptive management? Ecology and Society 13(1):14. [online] URL http://www.ecologyandsociety.org/vol13/iss1/art14/

Skelcher, C. 2005. Jurisdictional integrity, polycentrism, and the design of democratic governance. Governance 18(1):89110. http://dx.doi.org/10.1111/j.1468-0491.2004.00267.x

Sloan, M. 2005. Ocklawaha River Restoration: The Fate of the Rodman Reservoir. Pages 100-105 in J. T. Scholz, and B. Stiftel, editors. Adaptive Governance and Water Conflict: New Institutions for Collaborative Planning. Resources for the Future, Washington D. C., USA.

Smith, C. B. 2011. Adaptive management on the central Platte River-science, engineering, and decision analysis to assist in the recovery of four species. Journal of Environmental Management 92(5):1414-1419. http://dx.doi.org/10.1016/j.je nvman.2010.10.013

Stahl, C., A. Cimorelli, C. Mazzarella, and B. Jenkins. 2011. Toward sustainability: a case study demonstrating transdisciplinary learning through the selection and use of indicators in a decision-making process. Integrated 
Environmental Assessment and Management 7(3):483-498.

http://dx.doi.org/10.1002/ieam.181

Stringer, L. C., A. J. Dougill, E. Fraser, K. Hubacek, C. Prell, and M. S. Reed. 2006. Unpacking "participation" in the adaptive management of social-ecological systems: a critical review. Ecology and Society 11(2):39. [online] URL: http://w ww.ecologyandsociety.org/vol11/iss2/art39/

Volkman, J. M., and W. McConnaha. 1993. Through a glass, darkly: Columbia River salmon, the Endangered Species Act, and adaptive management. Environmental Law 23 (4):1249-1272.

Walker, B. H., L. H. Gunderson, A. P. Kinzig, C. Folke, S. R. Carpenter, and L. Schultz. 2006. A handful of heuristics and some propositions for understanding resilience in socialecological systems. Ecology and Society 11(1):13. [online] URL: http://www.ecologyandsociety.org/vol11/iss1/art13/

Walters, C. 1997. Challenges in adaptive management of riparian and coastal ecosystems. Conservation Ecology 1(2):1. [online] URL: http://www.consecol.org/vol1/iss2/art1/

Walters, C. J. 2002. Adaptive Management of Renewable Resources. The Blackburn Press. Caldwell, New Jersey.

Walters, C. 2007. Is adaptive management helping to solve fisheries problems? Ambio 36(4):304-307. http://dx.doi.org/1 0.1579/0044-7447(2007)36[304:IAMHTS]2.0.CO;2

Williams, B. K . 2011. Adaptive management of natural resources -framework and issues. Journal of Environmental Management 92(5):1346-1353. http://dx.doi.org/10.1016/j.je nvman.2010.10.041 
APPENDIX 1. IMC scores for the twelve watersheds in this study. Score of "1"=low, "2"=average, "3"=high.

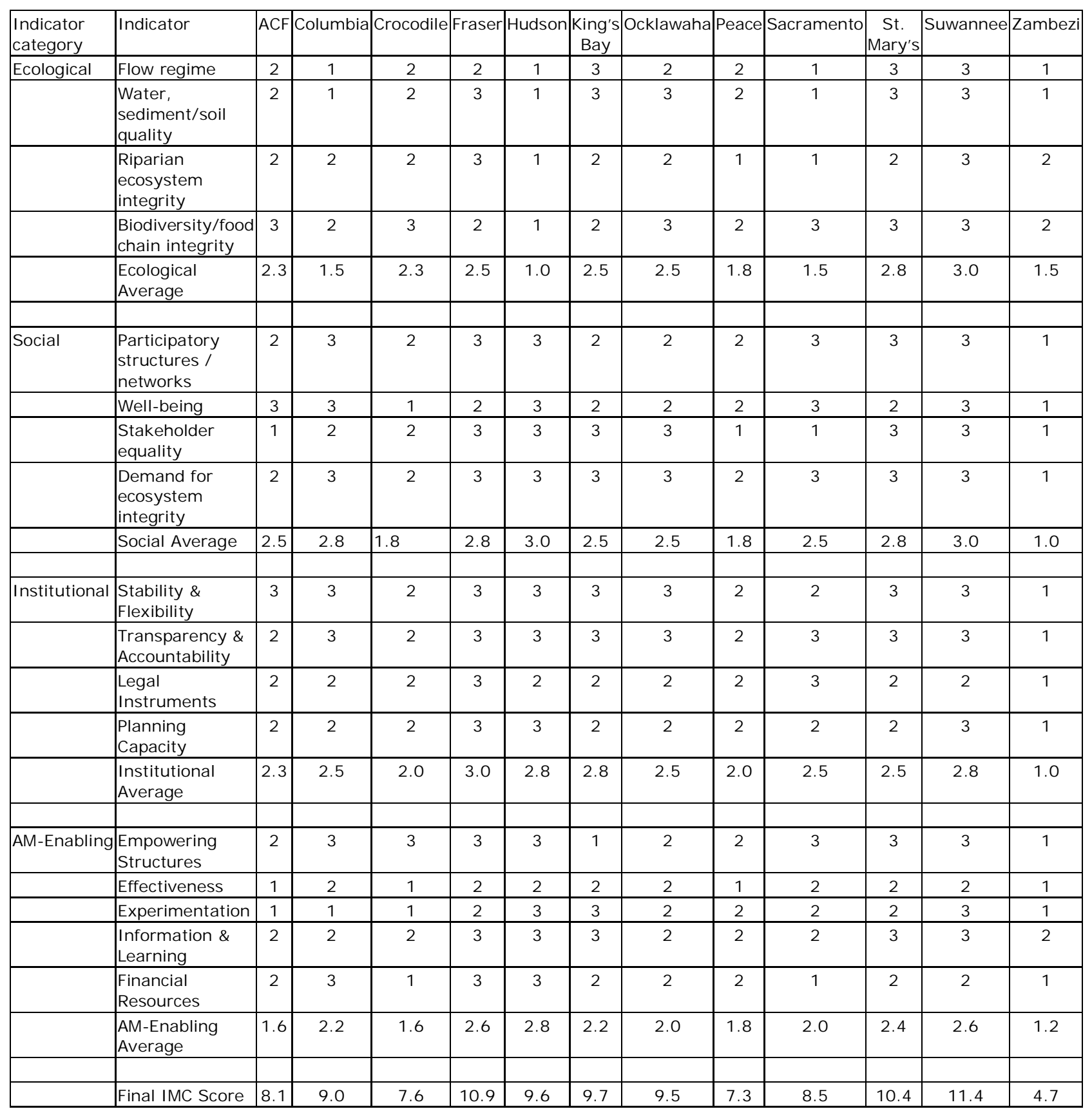

